\title{
A PROOF OF THE GREEN-OSHER INEQUALITY
}

\author{
YunLONG YANG AND PINGLIANG HUANG
}

Abstract. In this paper we give a different proof of the Green-Osher inequality and show that equality holds if and only if $\gamma$ is a circle when $F(x)$ is a strictly convex function on $(0,+\infty)$.

Mathematics subject classification (2010): 52A38, 52A40.

Keywords and phrases: Green-Osher's inequality, Bonnesen's inequality, minimal annulus.

\section{REFERENCES}

[1] T. Bonnesen, Les Problèmes des Isopérimètres et des Isépiphanes, Paris, Gauthier-Villars, 1929.

[2] T. Bonnesen And W. Fenchel, Theory of Convex Bodies, BCS Associates, Moscow, ID, 1987.

[3] Y. DAI, W. X. XU AND J. ZHou, Some Bonnesen style inequalities and planar isoperimetric deficit upper limit, Proceedings of The Fourteenth International Workshop on Diff. Geom., 14 (2010), 69-76.

[4] F. EdLeR, Vervollständigung der Steinerschen elementargeometrischen Beweise für den Satz, dass der Kreis grösseren Flächeninhalt besitzt als jede andere ebene Figur gleich grossen Umfangs, Nachr. Ges. Wiss. Göttingen, (1882), 73-80. [translated into French and printed in Bull. Sci. Math., 7 (1883), 198-204].

[5] M. E. GAGE, An isoperimetric inequality with applications to curve shortening, Duke Math. J., 50 (1983), 1225-1229.

[6] M. E. Gage, Curve shortening makes convex curves circular, Invent. Math., 76 (1984), 357-364.

[7] M. E. GAGE, On an area-preserving evolution equation for plane curves, in Nonlinear Problems in Geometry (D. M. DeTurck edited), Contemp. Math., 51 (1986), 51-62.

[8] M. E. Gage, Positive centers and the Bonnesen inequality, Proc. Amer. Math. Soc., 110 (1990), 1041-1048.

[9] M. E. GAGE AND R. S. HAMilton, The heat equation shrinking convex plane curves, J. Differential Geom., 23 (1986), 69-96.

[10] M. GREEN AND S. OSHER, Steiner polynomials, Wulff flows, and some new isoperimetric inequalities for convex plane curves, Asian J. Math., 3 (1999), 659-676.

[11] L. S. Jiang AND S. L. PAn, On a non-local curve evolution problem in the plane, Comm. Anal. Geom., 16 (2008), 1-26.

[12] G. LAWLOR, A new area-maximization proof for the circle, Math. Intelligencer, 20 (1998), 29-31.

[13] P. LAX, A short path to the shortest path, Amer. Math. Monthly, 102 (1995), 158-159.

[14] H. Martini and Z. Mustafaev, On isoperimetric inequalities in Minkowski space, J. Inequal. Appl., 2010, Art. ID 697954, 18pp.

[15] D. S. Mitrinović, J. E. PeČArić and V. Volenec, Recent Advances in Geometric Inequalities, Kluwer Academic Publishers Group, Dordrecht, 1989.

[16] K. Ou And S. L. PAn, Some remarks about closed convex curves, Pacific J. Math., 248 (2010), 393-401.

[17] S. L. Pan, X. W. Sun AND Y. D. Wang, A variant of the isoperimetric problem, Part I, Sci. China Ser. A, 51 (2008), 1119-1126.

[18] S. L. PAN AND J. N. YANG, On a non-local perimeter-preserving curve evolution problem for convex plane curves, Manuscripta Math., 127 (2008), 469-484.

[19] C. Peri AND A. Zucco, On the minimal convex annulus of a planar convex body, Monatsh. Math., 114 (1992), 125-133.

[20] C. Peri, J. M. Wills AND A. Zucco, On Blaschke's extension of Bonnesen's inequality, Geom. Dedicata, 48 (1993), 349-357. 
[21] L. A. Santaló, Integral Geometry and Geometric Probability, Addison-Wesley 1976.

[22] J. STEINER, Sur le maximum et le minimum des figures dans le plan, sur la sphère et dans l'espace en général, I and II, J. Reine Angew. Math. (Crelle), 24 (1842), 93-152 and 189-250.

[23] A. Treibergs, The Stong isoperimetric inequality of Bonnesen, University of Utah, 2006. http://www.math.utah.edu/ treiberg/isoperim/Bonn.pdf 